\title{
Exchange Rate Variability and Manufacturing Sector Performance in Ghana: Evidence from Cointegration Analysis
}

Abdallah Abdul-Mumuni

Department of Banking and Finance, University of Professional Studies

Accra, Ghana.

E-mail: aabdulmumuni@yahoo.co.uk or abdul.mumuni@upsamail.edu.gh (corresponding Email)

Received: March 12, 2016

Accepted: May 26, 2016

Published: June 17, 2016

doi:10.5296/ieb.v2i1.9626

URL: http://dx.doi.org/10.5296/ieb.v2i1.9626

\begin{abstract}
This study examined the effect of exchange rate variability on manufacturing sector performance in Ghana. Using time series data from the period 1986-2013 and employing the autoregressive distributed lag (ARDL) approach, the empirical results show that there exists both a short as well as long run relationship between exchange rate and manufacturing sector performance. Thus, in Ghana as the exchange rate appreciates, the manufacturing sector performance improves and as it depreciates, the sector is adversely affected. In view of this, it is recommended that policy should be put in place to regulate the importation of goods that could be locally produced so as to improve the performance of the manufacturing sector. In addition, the government should ensure that there is regular electricity supply, good roads, water and a reliable telecommunication system so that the manufacturing sector can perform effectively and efficiently in order to achieve a considerable rate of economic growth.
\end{abstract}

Keywords: Exchange rate, Manufacturing sector, Interest rate, Foreign direct investment, Imports, Cointegration, Vector error correction model 


\section{Introduction}

In Ghana, the Economic Recovery Programme (ERP) started in April 1983 with the first cedi devaluation; thereafter, the country sought for a progressive movement towards a realistic and flexible exchange rate. The policy package under the programme among other things, sought to: realign the exchange rates and interest rates; reform and restore productive incentives and achieve economic growth. In 1986, Ghana started with a two-window system, and moved to a dual exchange rate market. Window One maintained a fixed but adjustable exchange rate and Window Two used a weekly auction system. The rate in Window One was applicable to government transactions, petroleum imports, cocoa and other traditional export receipts. The rate in Window Two applied to all other transactions. In 1992, the government of Ghana decided to unify the two-window auction systems and replaced them by an interbank wholesale system in which a weekly wholesale auction is used to determine the interbank rate. Banks were the only institutions permitted to participate in the wholesale system. The government allowed the establishment of forex bureau outlets in the 1980s by private individuals and companies. With the introduction of this system, foreign exchange rate is determined on a daily basis in an interbank system under the supervision of the Bank of Ghana. The periodic adjustment of the exchange rate is to make it possible to improve price incentives in the country and ensure growth in the productive sectors of the Ghanaian economy.

In spite of the above arrangements, the Ghana cedi continues to experience frequent fluctuations and this consequently, affects the growth and development of the manufacturing sector. This situation in Ghana has prompted some researchers to undertake various studies on the effect of the exchange rate changes on some macroeconomic variables such as the domestic prices (Adu et al., 2015), trade balance (Bhattarail \& Armah, 2013), economic growth (Adu-Gyamfi, 2011) and employment growth (Mensah et al., 2013). However, to the best of my knowledge, there has not been any study on the extent to which these changes in the exchange rate specifically affect manufacturing output in Ghana. The study therefore seeks to fill this knowledge gap by empirically investigating the effects of exchange rate variability on manufacturing sector performance in Ghana. This study is important because any effect on the manufacturing subsector affects the real variables of the economy namely; output, income and employment.

The rest of the paper is structured as follows: section 2 reviews the theoretical and empirical literature. Section 3 discusses the methodology. Section 4 presents the results of the empirical analysis and section 5 contains the conclusion and policy recommendations.

\section{Related Literature}

The depreciation of the domestic currency may have either positive or negative effects on the performance of a country's manufacturing sector. Theoretically, there are a number of reasons for a contractionary effect of exchange rate depreciation. First, the depreciation of the exchange rate increases the price of traded goods, which feeds into the general price level rendering a negative real balance effect. This will, in turn, result in a fall in aggregate demand and output (Edwards, 1986). This leads to a reallocation of resources resulting in increased 
production in import competing sectors. Second, if the demand for imported goods is inelastic due to the dominance of capital and essential intermediate and consumers' goods in a country's import basket, then exchange rate depreciation may be contractionary (Upadhaya \& Upadhaya, 1999). Apart from these demand side channels, contractionary effects can also arise from the supply side (Edwards, 1986; Upadhaya \& Upadhaya, 1999). The increased cost of imported inputs might adversely affect production and for that matter, manufacturing sector performance in general. Krugman and Taylor (1978), using a Keynesian framework, have also identified certain conditions under which exchange rate depreciation or devaluation is found to be contractionary. These are (1) if initially imports exceed exports, (2) consumption propensity out of profits and wages are different, and (3) if government revenues are increased as a result of currency depreciation or devaluation.

On the other hand, as a direct consequence of currency depreciation, import prices go up, which is likely to depress the demand for imports in the domestic economy. Increased exports and reduced imports are expected to improve the external trade balance. Essentially, the depreciation of the local currency is also believed to contribute to the enhancement of external competitiveness stimulating production in the export sector. This will, however, depend on whether the country in question has satisfied the Marshall-Lerner condition or not. The Marshall-Lerner condition (named after English economist Alfred Marshall (1842-1924) and the Romanian born economist Abba Lerner (1905) states that exchange rate depreciation would result in an increase in the level of output if the sum of the price elasticity of demand for imports and exports is greater than unity. According to Lotfalipour et al. (2013), exchange rate increase may increase the demand for domestic products and the cost of imported capital and other imported inputs. It will cause investment increase only if the impact on demand is more than the cost effect.

There are numerous empirical studies that have assessed the relationship between exchange rate variability and manufacturing sector performance. Azeez et al. (2012) find that oil revenue and balance of payment exert negative effects while exchange rate volatility contributes positively to GDP in the long run. Also, Ehinomen and Olodipo (2012) find that in Nigeria, exchange rate appreciation has a significant relationship with domestic output and will promote the growth of the manufacturing sector. Ubok-Udom (1999) examined the relationship between exchange rate changes and the growth of domestic output in the Nigerian economy from 1971 to 1995 and found that exchange changes have a negative sign in the estimated equations. He asserted that the rate of growth of total GDP and non-oil GDP tends to fall or rise with nominal Naira/US dollar exchange rate. This implies that the Nigerian economy apparently requires exchange rate appreciation for it to achieve high growth rate. Similarly, Ukoha (2000) carried out an empirical study of the determinants of capacity utilization in the Nigerian manufacturing industry between 1970 and 1998 and his results revealed that exchange rate had a positive effect on manufacturing capacity utilization. Again, Kandilov and Leblebicioğlu (2011) find a robust negative impact of exchange rate volatility on plant investment. Goldberg (1993) finds that a real depreciation (appreciation) of the U.S. dollar was likely to generate an expansion (reduction) in investment in the 1970s, but that the opposite pattern prevailed during the 1980s. Using an error correction methodology, 
Landon and Smith (2009) estimated the aggregate and sector-level investment equations for a panel of 17 OECD countries. The authors found that real currency depreciation may reduce aggregate investment and investment of nine sectors in the short run. Furthermore, it causes reduction of aggregate investment in the long run.

However, Campa and Goldberg (1999) compare the investment sensitivity to exchange rate in the United States, United Kingdom, Japan, and Canada for the period 1970-1993, and find investment in Canada to be the least responsive to exchange rate movements.

The empirical evidence so far on the effects of currency adjustments on manufacturing sector performance is inconclusive and so country-specific studies are the best possible option to guide policy directions.

\section{Methodology and Data Source}

The objective of this study is to contribute to the relevant macroeconomic policy discourse more effectively by carrying out an empirical investigation of the effects of exchange rate variability on manufacturing sector performance in Ghana from 1986 to 2013. In order to achieve this research objective, the autoregressive distributed lag (ARDL) model is applied. Following Mmaduabuchi and Ifeanyi (2014), the basic model employed in this study is stated as follows:

$$
\operatorname{ManGDP}_{t}=\alpha_{0}+\alpha_{1} \text { ExRate }_{t}+\alpha_{2} \mathrm{IMP}_{t}+\alpha_{3} F D I_{t}+\alpha_{4} I R_{t}+\mu_{t}
$$

Where ManGDP represents manufacturing as a percentage of gross domestic product (GDP), ManGDP is used here as a proxy for manufacturing sector performance. ExRate is the nominal exchange rate, IMP represents total imports and FDI is foreign direct investment, In line with existing studies on developing countries, nominal interest rate (IR) is included in the model (Mmaduabuchi \& Ifeanyi, 2014; Caglayan \& Torres, 2008). $\mu$ is the white noise error term.

Equation (1) is further expressed in a log-linear form and stated as follows:

$$
\operatorname{lnManGDP}_{t}=\alpha_{0}+\alpha_{1} \ln \text { ExRate }_{t}+\alpha_{2} \ln \mathrm{IMP}_{t}+\alpha_{3} \ln F D I_{t}+\alpha_{4} \operatorname{lnIR} R_{t}+\mu_{t}
$$

The log-linear model was chosen because of the following reasons: Firstly, to find the percentage change in the dependent variable resulting from percentage changes in the independent variables. Secondly, the use of log transformation is necessary because it compresses the scale in which the variables are measured, reducing a tenfold difference between two values to a twofold difference. This reduces the possibility of heteroskedasticity in the model (Gujarati, 1995).

Equation (2) is a long run equilibrium model which may form a cointegrating set if all the variables are cointegrated of order 1. Exchange rate is expected to have a positive effect on manufacturing sector performance. However, imports are expected to have a negative effect on manufacturing sector performance. FDI is expected to have a positive effect on manufacturing sector performance. Finally, interest rate is expected to have a negative effect 
on manufacturing sector performance. Annual data from World development indicators of World Bank, (2014) was used for the analysis.

\subsection{Variance Inflation Factor (VIF) Test}

A VIF test was carried out to establish the existence of multicollinearity among all the explanatory variables in the model. According to Gujarati and Porter (2009), in cases of near or high multicollinearity, the ordinary least square (OLS) estimators have large variances and covariances, making precise estimation difficult.

\subsection{Unit Root Test}

To ensure that the series are stationary, a unit root test was carried out using the Phillips-Perron (PP) and Augmented Dickey-Fuller (ADF) tests. The PP test is, however, preferred to the traditional ADF test because of its use of non-parametric methods to adjust for serial correlation and endogeneity of regressors thereby preventing the loss of observations implied by the ADF test.

\subsection{ARDL Model Specification}

In order to investigate the long run relationship and dynamic interactions among the variables, the model is estimated using the autoregressive distributed lag (ARDL) approach to cointegration as developed by Pesaran et al. (2001). This approach allows the estimation of both short run and long run coefficients of a single equation. The coefficients of this approach are unrestricted and so the short run dynamics are not dictated by the long run equilibrium relationship. The ARDL approach has an advantage over other cointegration methods (such as the fully modifed OLS, dynamic OLS and Johansen, 1988) in that it performs better in small samples (Pesaran \& Shin, 1999). Another advantage of the approach is that it works even when the underlying variables are integrated of order zero $\{\mathrm{I}(0)\}$ only, integrated of order one $\{\mathrm{I}(1)\}$ only or a mixture of I(0)/ I(1) (Pesaran \& Shin, 1999). Cointegration methods such as the methods by Engle and Granger (1987), Johansen (1988) and Stock and Watson (1988) concentrate on cases in which the underlying variables are integrated of order one $\{$ I(1) $\}$ only (Pesaran, Shin \& Smith, 2001).

Furthermore, the ARDL model is advantageous because it corrects for residual serial correlation and the problem of endogenous regressors by using the lags as instruments.

Following Pesaran et al. (2001), the vector autoregression (VAR) of order $p$, denoted VAR $(p)$ is stated for the following manufacturing sector performance function:

$$
Z_{t}=\beta_{0}+\alpha_{t}+\sum_{i=1}^{p} \phi_{i} z_{t-i}+\varepsilon_{t} \quad \mathrm{t}=1,2,3,4, \ldots \mathrm{T}
$$

Where $Z_{t}$ is a vector of $m_{t}$ and $x_{t} . m_{t}$ is the dependent variable and represents manufacturing sector performance. $x_{t}$ is the vector matrix and represents a set of explanatory variables while $t$ is a time or trend variable. $\beta_{0}$ represents $(\mathrm{k}+1)$-a vector of intercept (drift) and $\alpha_{t}$ represents $(\mathrm{k}+1)-\mathrm{a}$ vector of trend coefficients. 
The vector error correction model (VECM) of the series can be specified as follows:

$$
\Delta z_{t}=\mu+\beta_{0}+\rho z_{t-i}+\sum_{i=1}^{p-i} \gamma_{i} \Delta m_{t-i}+\sum_{i=1}^{p-i} \gamma_{i} \Delta x_{t-i}+\varepsilon_{t} \quad \mathrm{t}=1,2,3,4, \ldots \mathrm{T}
$$

Where $\Delta$ is the difference operator and the long run multiplier matrix is stated as follows:

$$
\rho=\left[\begin{array}{cc}
\rho m m & \rho m x \\
\rho x m & \rho x x
\end{array}\right]
$$

The diagonal elements of the matrix are unrestricted. Thus, the selected series can be either $\mathrm{I}(0)$ or I(1). If $\rho m m=0$, then $m=\mathrm{I}(1)$. On the other hand, if $\rho m m<0$, then $m=I(0)$. The VECM procedures are imperative in the testing of at most one cointegrating vector between the dependent variable $m_{t}$ and a set of regressors $x_{t}$. After the restrictions $\rho m m=0, \mu \neq 0$, and $\alpha=0$ are imposed, the effect of exchange rate variability on manufacturing sector performance can be stated as the following unrestricted error correction model (UECM):

$$
\begin{aligned}
& \Delta(\operatorname{lnManGDP})_{t}=\beta_{0}+\beta_{1}(\operatorname{lnManGDP})_{t-i}+\beta_{2}(\operatorname{lnExRate})_{t-i}+\beta_{3}(\operatorname{lnIMP})_{t-i}+\beta_{4}(\operatorname{lnFDI})_{t-i}+\beta_{5}(\operatorname{lnIR})_{t-i} \\
& +\sum_{i=1}^{p} \beta_{1 i} \Delta(\operatorname{lnManGDP})_{t-i}+\sum_{j=1}^{q} \beta_{2 j} \Delta(\ln E x R a t e)_{t-j}+\sum_{k=1}^{q} \beta_{3 k} \Delta(\operatorname{lnIMP})_{t-k}+ \\
& \sum_{m=1}^{q} \beta_{4 m} \Delta(\operatorname{lnFDI})_{t-m}+\sum_{n=1}^{q} \beta_{5 n} \Delta(\operatorname{lnIR})_{t-n}+\mu_{t}
\end{aligned}
$$

Where $\Delta$ still represents the first difference operator and $\mu_{t}$ is the white noise disturbance term. Equation (5) shows that manufacturing sector performance is influenced and explained by its past values. In addition, the F-Wald test was done so as to differentiate the long run relationship between the concerned variables by imposing restrictions on the estimated long run coefficients of the manufacturing as a percentage of GDP, exchange rate, imports, FDI and interest rate. The null and alternative hypotheses are stated as follows: $\beta_{0}=\beta_{1}=\beta_{2}=\beta_{3}=\beta_{4}=0 \quad$ against the alternative hypothesis, $H_{a}: \beta_{0} \neq \beta_{1} \neq \beta_{2} \neq \beta_{3} \neq \beta_{4} \neq 0$

The test which normalizes on $M a n G D P$ is denoted by

$$
F_{M a n G D P}(\text { ManGDP | ExRate, IMP, FDI, IR) }
$$

In the ARDL approach, two asymptotic critical values provide a test for cointegration when the independent variables are $\mathrm{I}(\mathrm{d})$ (where $0 \leq d \leq 1)$ : a lower value assuming the regressors are $\mathrm{I}(0)$ and an upper value assuming purely $\mathrm{I}(1)$ regressors. When the F-statistic is greater than the upper critical value, it implies that the null hypothesis of no long-run relationship is rejected regardless of the orders of integration for the time series. This implies that there is long run relationship among the series. If the F-statistic is less than the lower critical value, we fail to reject the null hypothesis and this implies that there is no long-run relationship among the series. Lastly, if the F-statistic falls between the lower and the upper critical values, the result is inconclusive.

When cointegration is established, the conditional ARDL ( $p, q 1, q 2, q 3, q 4)$, the long-run 


\section{Macrothink}

model for $\operatorname{ManGDP}_{t}$ is estimated as follows:

$$
\begin{aligned}
& \operatorname{lnManGDP} t=\beta_{0}+\sum_{i=1}^{p} \beta_{1} \operatorname{lnManGDP}_{t-1}+\sum_{i=0}^{q 1} \beta_{2} \operatorname{lnExRate}_{t-1}+\sum_{i=0}^{q 2} \beta_{3} \operatorname{lnIMP}_{t-1}+\sum_{i=0}^{q 3} \beta_{4} \operatorname{lnFDI}_{t-1}+ \\
& \sum_{i=0}^{q 4} \beta_{5} \operatorname{lnIR}{ }_{t-1}+\mu_{t}
\end{aligned}
$$

It involves selecting the optimal lag length of the $\operatorname{ARDL}(p, q 1, q 2, q 3, q 4)$ model in the four variables using the Akaike Information Criterion (AIC).

Finally, an Error Correction Model (ECM) estimates are obtained. The ECM provides the means of reconciling the short-run behaviour of an economic variable with its long-run behavior. The ECM representation of the series is specified as follows:

$$
\begin{aligned}
& \Delta \operatorname{lnManGDP}_{t}=\beta_{0}+\sum_{i=1}^{p} \beta_{1 i} \Delta \operatorname{lnManGDP}_{t-1}+\sum_{i=0}^{q 1} \beta_{2 j} \Delta \operatorname{lnExRate}_{t-1}+ \\
& \sum_{i=0}^{q 2} \beta_{3 k} \Delta \operatorname{lnIMP}_{t-1}+\sum_{i=0}^{q 3} \beta_{4 m} \Delta \ln \mathrm{FDI}_{t-1}+\sum_{i=0}^{q 4} \beta_{5 n} \Delta \operatorname{lnIR}_{t-1}+\varphi E C M_{t-1}+\mu_{t}
\end{aligned}
$$

Where $\varphi$ is the speed of adjustment parameter and the ECM is the error correction term. The coefficient $\varphi$ is expected to be negative and statistically significant to further confirm that a cointegrated relationship exists.

\section{Empirical Analysis}

Before estimating the model, the unit root and cointegration tests were analysed. Regressions with non-stationary data have a high potential of leading to spurious relationship. The PP and ADF tests were therefore conducted in order to establish stationarity in the series. The results are presented in Table 1.

Table 1. Unit root test

\begin{tabular}{lllll}
\hline Variable & PP Test & & ADF Test \\
\cline { 2 - 5 } & Levels & $1^{\text {st }}$ Difference & Levels & $1^{\text {st }}$ Difference \\
\hline LnManGDP & 0.783 & $-4.078^{* * *}$ & 0.771 & $-4.101^{* * *}$ \\
LnExRate & -3.031 & $-4.147^{* * *}$ & -3.215 & $-4.083^{* * *}$ \\
LnFDI & -1.047 & $-4.571^{* * *}$ & -1.044 & $-4.595^{* * *}$ \\
LnIMP & 0.829 & $-4.749^{* * *}$ & 0.757 & $-4.757^{* * *}$ \\
LnIR & -1.149 & $-5.501 * * *$ & -1.165 & $-5.492^{* * *}$ \\
\hline
\end{tabular}

Note. Unit root tests were performed in Stata 13. ***,**,* indicate the rejection of the null hypothesis of unit root at $1 \%, 5 \%$ and $10 \%$ level of statistical significance respectively.

As it can be seen from table 1, at levels, none of the variables was stationary which implies 
that the null hypothesis of unit root is accepted. However, after taking the first difference, all the variables became stationary.

\subsection{Results of the ARDL Test for Cointegration}

The conditional VECM by ordinary least square was estimated in order to test for the presence of long run relationship among the variables. Thus, an F-test was conducted for the joint significance of the coefficients of the variables. The results of the computed F-statistic when each variable is normalised (that is, considered as a dependent variable) in the ARDL-OLS regressions are presented in Table 2.

Table 2. Testing for existence of cointegration among the variables in the ARDL model

\begin{tabular}{|c|c|c|c|c|c|c|c|c|}
\hline \multirow[t]{2}{*}{ F-Statistic } & $99 \%$ Lower & $99 \%$ & Upper & $95 \%$ Lower & $95 \% \quad$ Upper & $90 \%$ Lower & $90 \%$ & Upper \\
\hline & Bound & Bound & & Bound & Bound & Bound & Bound & \\
\hline 5.500 & 3.74 & 5.06 & & 2.86 & 4.01 & 2.45 & 3.52 & \\
\hline
\end{tabular}

Results were obtained from Stata 13.0.

Note. ${ }^{*}$ Critical values based are on Narayan (2004).

The F-test for the joint significance of the lagged level variables is conducted by appealing to the Wald test. The 1\% lower and upper bound critical values provided by Narayan (2004) are 3.74 and 5.06. The calculated F-statistic shows that there exists long-run relationship among the variables because the test value of 5.500 is above the upper bound critical value.

Table 3. Estimated long run coefficients using the ARDL Approach ARDL(1,0,1,1,2) selected based on Akaike information criterion

\begin{tabular}{|c|c|c|c|c|}
\hline \multicolumn{5}{|c|}{ Dependent variable is lnManGDP 26 observations used for estimation from 1988 to 2013} \\
\hline & Regressor Coefficient & Standard Error & T-Ratio & Prob \\
\hline LnExRate & $0.12082 * * *$ & 0.036183 & 3.3391 & 0.004 \\
\hline LnIMP & $-.30957 * *$ & 0.11653 & -2.6566 & 0.017 \\
\hline $\operatorname{lnFDI}$ & -0.012453 & 0.040470 & -0.30771 & 0.762 \\
\hline $\ln I R$ & 0.17474 & 0.11383 & 1.5351 & 0.144 \\
\hline $\mathrm{C}$ & 8.8143 & 2.2932 & 3.8437 & 0.001 \\
\hline
\end{tabular}

Note. $* * *, * *$, and $*$ denote the rejection of the null hypotheses at $1 \%, 5 \%$ and $10 \%$ levels of significance. Results were obtained from Microfit 5.0.

The results from Table 3 show that the effect of exchange rate on manufacturing sector performance is positive and statistically significant at $1 \%$. The estimates indicate that all other factors held constant, in the long run, a 1 percent increase in exchange rate will lead to 
an increase in manufacturing sector performance by 0.12 percent. This is so because as the exchange rate increases, the manufacturing sector is motivated to contribute more to the GDP. This result is consistent with Edwards (1989), Innocent et al. (2013) and Clement (2014). A coefficient of approximately -0.30957 for imports means that all other things being equal, in the long run a 1 percent increase in imports will lead to a decrease in manufacturing sector performance by about $0.31 \%$ and this is statistically significant at $5 \%$. The implication of this result is that a greater portion of manufacturers' inputs are imported and so as imports increase, the contribution of the manufacturing sector to GDP reduces. Again, a coefficient of -0.012453 for FDI implies that ceteris paribus, a 1 percent increase in FDI will lead to a decrease in manufacturing sector's contribution to GDP by about 0.013 percent but this is not significant. Finally, in the long run, an increase in interest rate by $1 \%$ will lead to an increase in manufacturing sector performance by about $0.17 \%$ holding other factors constant.This result is also insignificant.

Table 4. Diagnostic tests results

\begin{tabular}{|c|c|c|}
\hline Test Statistic & LM VERSION & F VERSION \\
\hline A. Serial Correlation & $\operatorname{CHSQ}(1)=0.96151[0.327]$ & $\mathrm{F}(1,15)=0.57623[0.350]$ \\
\hline B. Functional Form & $\operatorname{CHSQ}(1)=5.5301[0.112]$ & $1.9540[.132]$ \\
\hline C. Normality & $\operatorname{CHSQ}(2)=0.087555[.957]$ & Not applicable \\
\hline D:Heteroskedasticity & $\operatorname{CHSQ}(1)=2.4839[0.115]$ & $\mathrm{F}(1,24)=2.5350[0.124]$ \\
\hline \multicolumn{3}{|c|}{ A:Lagrange multiplier test of residual serial correlation } \\
\hline \multicolumn{3}{|c|}{ B:Ramsey's RESET test using the square of the fitted values } \\
\hline \multicolumn{3}{|c|}{$\mathrm{C}:$ Based on a test of skewness and kurtosis of residuals } \\
\hline \multicolumn{3}{|c|}{ D:Based on the regression of squared residuals on squared fitted values } \\
\hline \multicolumn{3}{|c|}{$\begin{array}{l}\text { The results of the diagnostic tests in table } 4 \text { indicate that the model has the aspiration of econometric } \\
\text { properties. They show that the model has no serial correlation and heteroskedasticity. The model has a correct } \\
\text { functional form and normality assumption is also satisfied. }\end{array}$} \\
\hline
\end{tabular}

Table 5. VIF test

\begin{tabular}{lll}
\hline Variable & VIF & 1/VIF \\
\hline lnIMP & 20.29 & 0.049296 \\
$\operatorname{lnFDI}$ & 11.14 & 0.089773 \\
$\operatorname{lnExRate}$ & 6.10 & 0.164066 \\
$\operatorname{lnIR}$ & 2.58 & 0.387360 \\
Mean VIF & 10.03 & \\
\hline
\end{tabular}

In Table 5, it is seen clearly that even though some of the variables have a high VIF, the key variable, lnExRate shows a VIF of 6.10 which is acceptable. Multicollinearity can therefore be safely ignored. The "do nothing" school of thought expressed by Blanchard (1967) states 
that "multicollinearity is essentially a data deficiency problem and sometimes we have no choice over the data we have available for empirical analysis (Gujarati \& Porter, 2009).

Table 6. Error correction representation for the selected ARDL model ARDL $(1,0,1,1,2)$ selected based on Akaike information criterion

\begin{tabular}{|c|c|c|c|c|c|}
\hline \multicolumn{6}{|c|}{ Dependent variable is dlnMANGDP 26 observations used for estimation from 1988 to 2013} \\
\hline & \multicolumn{2}{|c|}{ Regressor Coefficient } & Standard Error & T-Ratio & Prob \\
\hline$\Delta \operatorname{lnExRate}$ & \multicolumn{2}{|l|}{0.052909} & 0.02054 & $2.57581 * *$ & 0.019 \\
\hline$\Delta \operatorname{lnIMP}$ & \multicolumn{2}{|l|}{-0.011463} & 0.074188 & -0.15451 & 0.879 \\
\hline$\Delta \ln F D I$ & \multicolumn{2}{|l|}{0.054647} & 0.119646 & $2.7815^{* *}$ & 0.012 \\
\hline$\Delta \ln I R$ & \multicolumn{2}{|l|}{0.33010} & 0.053764 & 0.61399 & 0.547 \\
\hline$\Delta \operatorname{lnIR} 1$ & \multicolumn{2}{|l|}{-0.12037} & 0.548891 & $-2.4620^{* *}$ & 0.024 \\
\hline CONSTANT & \multicolumn{2}{|l|}{3.8599} & 1.5736 & 2.4529 & 0.024 \\
\hline $\operatorname{Ecm}(-1)$ & \multicolumn{2}{|l|}{-0.43791} & 0.13177 & -3.33234 & 0.004 \\
\hline \multicolumn{6}{|c|}{$\mathrm{ecm}=$ LNMANGDP $-.12082 *$ LNEXRATE $+.30957 *$ LNIMP $+.012453 *$ LNFDI $-.17474 *$ LNIR $-8.8143 * \mathrm{C}$} \\
\hline \multicolumn{2}{|l|}{ R-Squared } & 0.67519 & \multicolumn{2}{|c|}{ R-Bar-Squared } & 0.49249 \\
\hline \multicolumn{2}{|c|}{ S.E. of Regression } & 0.042973 & \multicolumn{2}{|l|}{ F-stat. } & $\mathrm{F}(6,19)=5.5434[.002]$ \\
\hline \multicolumn{2}{|c|}{ Mean of Dependent Variable } & -0.20707 & \multicolumn{2}{|c|}{ S.D. of Dependent Variable } & 0.660322 \\
\hline Residual Sum & Squares & 0.042973 & Equation & kelihood & 41.0320 \\
\hline Akaike Info. C & terion & 41.2457 & Schwarz & an Criterion & 34.9552 \\
\hline DW-statistic & & & 2.3133 & & \\
\hline
\end{tabular}

Note. $* * *$ and $* *$ denote the rejection of the null hypotheses at $1 \%$ and $5 \%$ levels of significance respectively.

The adjusted R-squared value of 0.49 indicates that about $49 \%$ of the changes in manufacturing sector performance are explained by changes in the independent variables. The regression model is said to be significant at $1 \%$ following the F-statistic of 5.54. The empirical findings from the error-correction model show that manufacturing sector performance adjusts towards long run equilibrium at the speed of about $44 \%$. A coefficient of 0.053 for exchange rate indicates that all other factors remaining constant, in the short-run, a 1 percent increase in the exchange rate will lead to an increase in manufacturing sector performance by 0.053 percent and statistically significant at $5 \%$. This is so because as the Ghana Cedi appreciates in value, the manufacturing sector is motivated to produce more thereby increasing its contribution to the GDP. A coefficient of approximately -0.011463 for imports means that in the short run, a 1 percent increase in imports will lead to a decrease in manufacturing sector performance by about $0.01 \%$ all other factors remaining the same. This result, however, is statistically insignificant. Again, the results show that in the short run, a 1 percent increase in FDI will lead to an increase in manufacturing sector performance by about 0.055 percent all other factors being equal and this is statistically significant at $5 \%$. Finally, in the short run, interest rate has a negative influence on manufacturing sector performance and statistically significant at 5\% level. The results show that all things being equal, in the short 


\section{Macrothink}

run, a 1 percent increase in interest rate (one year lag) will lead to a decrease in manufacturing sector performance by about 0.12 percent.

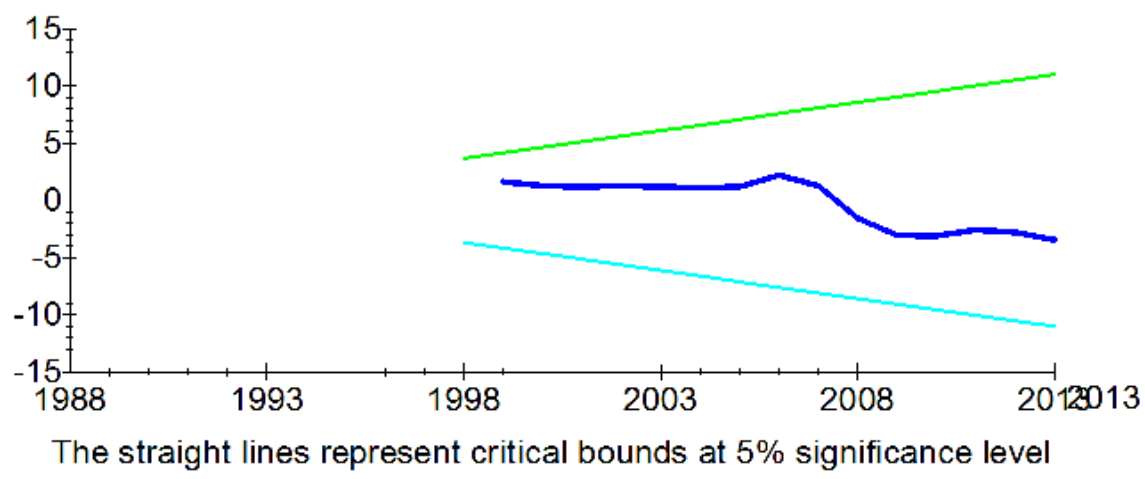

Figure 1. Plot of cumulative sum of recursive residuals (CUSUM)

Source: Author, 2016.

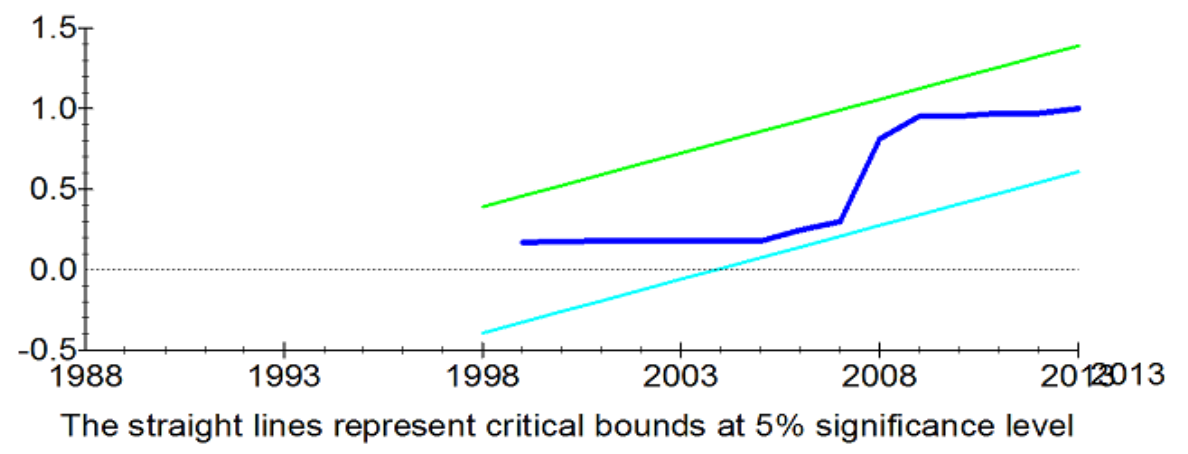

Figure 2. Plot of cumulative sum of squares of recursive residuals (CUSUMSQ)

Source: Author, 2016.

Figures 1 and 2 show a graphical representation of the Cumulative Sum (CUSUM) and Cumulative Sum of Square (CUSUMSQ) plots applied to the error correction model. Both plots are within the critical bounds and so we can conclude that the model is structurally stable.

\section{Conclusion}

The study investigated the cointegrating relationships among manufacturing sector performance, exchange rate, imports, FDI and interest rate using the ARDL approach. With the rising importance of the manufacturing sector in the growth and development process, the study investigates whether the sector's contribution to GDP is affected by disturbances emanating from the foreign exchange market. The results from the error-correction model 
show that in Ghana, manufacturing sector performance adjusts slowly to its equilibrium. However, empirical findings show that in the long- run, the growth of the manufacturing sector is positively related to exchange rate but negatively related to imports. The findings of this study are generally supportive of the contention of other researchers (Innocent et al., 2013; Opaluwa et al., 2010) that exchange rate has a significant effect on manufacturing sector performance.

\section{Policy Recommendation}

It is recommended that the government should put in place policy to regulate the importation of goods that could otherwise be produced locally so as that the performance of the manufacturing sector could improve. Additionally, problems such as irregular supply of electricity and water, poor roads, high interest rates should be addressed so as to boost manufacturing sector output. Finally, the government should develop and implement exchange rate policies that are aimed at minimizing currency fluctuations in the country. These policies would insulate manufacturing sector performance from the adverse effects of this exchange rate variability in Ghana.

\section{References}

Adu, G., Karimu, A., \& Mensah, J. T. (2015). An Empirical Analysis of Exchange Rate Dynamics and Pass-Through Effects on Domestic Prices in Ghana. International growth centre working paper.

Adu-Gyamfi. (2011). Assessing the impact of exchange rate volatility on economic growth in Ghana. Master thesis submitted to the Department of Economics, Kwame Nkrumah University of Science and Technology, Kumasi. Ghana.

Asia. Journal of Development Studies, 35, 89-103. http://dx.doi.org/10.1080/00220389908422603

Azeez, B. A., Kolopo, F. T., \& Ajayi, L. B. (2012). Effect of exchange rate volatility on macroeconomic performance in Nigeria. Interdisciplinary Journal of Contemporary Research in Business, 4(1), 149-155.

Bhattarai, K. B., \& Armah, M. K. (2005). The Effects of Exchange Rate on the Trade Balance in Ghana: Evidence from Co integration Analysis Research Memorandum. University of Hull.

Blankard, O. J. (1967). Comment. Journal of Business and Economic Statistics, 5, 449-451.

Caglayan, M., \& Rebeca, I. M. T. R. I. (2008). The Effect of the Exchange Rates on Investment in Mexican Manufacturing Industry. Warwick Economic Research Papers No. 846.

Campa, J., \& Goldberg, L. S. (1995). Investment in manufacturing, exchange rates and external exposure. Journal of International Economics, 38(3-4), 297-320. http://dx.doi.org/10.1016/0022-1996(94)01348-V 
Campa, J. M., \& Goldberg, L. (1999). Investment, pass-through, and exchange rates: a cross-country comparison. International Economic Review, 40(2).

Clement, J. O. (2014). The impact of real exchange rate fluctuation on industrial output in Nigeria. Journal of Policy and Development Studies, 9(1).

Edwards, S. (1989). Real Exchange Rate, Devaluation and Adjustment: Exchange Rate Policies in Developing Countries. MIT Press: Massachusetts.

Gujarati, D. N., \& Porter, D. C. (2009). Basic Econometrics (5rd ed.). New York: McGraw-Hill.

Gujarati, D. N. (1995). Basic Econometrics (3rd ed.). New York: McGraw-Hill.

Innocent, E. C., Matthew, O. M., \& Chike, N. (2013). Effect of exchange rate fluctuations on manufacturing sector in Nigeria. European Journal of Business and Management, $5(22)$.

Kandilov, T., \& Leblebicioğlu, A. (2011). The impact of exchange rate volatility on plant-level investment: Evidence from Colombia, Journal of Development Economics, 94, 220-230. http://dx.doi.org/10.1016/j.jdeveco.2010.01.013

Krugman, P., \& Taylor, L. (1978). Contractionary effects of devaluation. Journal of International Economics, 445-456.

Landon, S., \& Smith, C. E. (2007). The exchange rate and machinery and equipment imports: identifying the impact of import source and export destination country currency valuation changes. North American Journal of Economics and Finance, 18, 3-21. http://dx.doi.org/10.1016/j.najef.2006.08.001

Lotfalipour, M. R., Ashena, M., \& Zabihi, M. (2013). Exchange rate impacts on investment of manufacturing sectors in Iran. Business and Economic Research, 3(2). http://dx.doi.org/10.5296/ber.v3i2.3716

Mensah, M., Awunyo-Vitor, D., \& Asare-Menako, H. (2013). Exchange rate volatility and employment growth in Ghana's manufacturing sector. International Journal of Business and Social Science, 4(4).

Nucci, F., \& Pozzolo, A. (2001). Investment and the exchange rate: An analysis with firm-level panel dat. European Economic Review, 45, 259-283.

Opaluwa, D., Umeh, J. C., \& Ameh, A. A. (2012). The effect of exchange rate fluctuations on the Nigerian manufacturing sector. African Journal of Business Management, 4(14), 2994-2998.

Pesaran, H., Shin, Y., \& Smith, R. (2001). Bounds testing approaches to the analysis of level relationships. Journal of Applied Econometrics, 16(3), 289-326.

Ukoha, O. O. (2000). Determinants of Manufacturing Capacity Utilization in Nigeria, 1970-1998. The Nigeria Journal of Economics and Social Studies, 42(2), 121-130. 


\section{Macrothink}

Issues in Economics and Business

ISSN 2377-2301

2016, Vol. 2, No. 1

Upadhyaya, K., \& Upadhyay, M. (1999). Output effects of devaluation: Evidence from Asia. $\begin{array}{lllll}\text { Journal of } & \text { Development }\end{array}$ http://dx.doi.org/10.1080/00220389908422603

World Bank (2014). World Development Indicators, 2014, World Bank, Washington, DC.

\section{Copyright Disclaimer}

Copyright for this article is retained by the author(s), with first publication rights granted to the journal. This is an open-access article distributed under the terms and conditions of the Creative Commons Attribution license (http://creativecommons.org/licenses/by/3.0/). 